\title{
A választói viselkedés térbeli modellje - empirikus kísérlet budapesti adatok alapján
}

\section{A spatial model of voting behaviour - an empirical study based on Budapest data}

\author{
BÁLINT LAJOS, DARÓCZI GERGELY, BOZSONYI KÁROLY, \\ TÓTH GERGELY
}

BÁLINT Lajos: tudományos munkatárs, KSH Népességtudományi Kutatóintézet, Budapest; balint@demografia.hu

DARÓcZI Gergely: PhD-hallgató, vezető fejlesztő, Easystats Magyarország Kft., Budapest; daroczig@rapporter.net

BOZSONYI Károly: intézetvezető egyetemi docens, Károli Gáspár Református Egyetem, Társadalom- és Kommunikációtudományi Intézet, Budapest; bozsonyi.karoly@kre.hu TÓTH Gergely: PhD-hallgató, kutatásvezető, Easystats Magyarország Kft.; tudományos segédmunkatárs, MTA-ELTE Peripato Kutatócsoport, Budapest; gergely.toth@rapporter.net

KULCSSZAVAK: térbeli szűrés, területi választáskutatás, térbeli modellezés, Budapest

ABSZTRAKT: A tanulmány a választói magatartás térbeli modellezésének a hazai környezetben nem közismert módszerét mutatja be. Az adatbázis nyilvánosan elérhető, szavazóköri adatokból épült fel. A címlistában szereplő fővárosi szavazóköri adatokat geokódoltuk és az úgynevezett Getis-féle nemparaméteres szürés segítségével elemeztük. Ez annyit jelent, hogy a modellbe beléptetett függő és független változókat térbeli és térbeli hatástól mentes összetevőkre bontottuk. Eredményeink szerint a nem megfelelően felépített, a térbeli hatást figyelmen kívül hagyó modellek hamis következtetéshez vezettek. A térbeliség markáns szerepének felismerése jól mutatja a választási előrejelzésekben a standard közvélemény-kutatói módszertan határait. Az erős szignifikáns pozitív autokorreláció jelenléte a választási adatoknál arra enged következtetni, hogy a társadalmi-gazdasági kontextus sokat számít az emberi magatartások, döntések világában. A választók nem triviális eloszlása a térben új kihívások elé állítja a reprezentatív minták tervezését és a belőlük való következtetések elméletét.

Lajos BÁLINT: research fellow, Demographic Research Institute, Hungarian Central Statistical Office, Budapest; balint@demografia.hu

Gergely DARÓCZI: PhD student, chief developer of Easystats Ltd, London; daroczig@rapporter.net Károly BOZSONYI: associate professor, head of institute, Social and Communication Studies Institute, Károli Gáspár University of the Reformed Church in Hungary, Budapest; bozsonyi.karoly@kre.hu

Gergely TÓTH: PhD student, senior researcher, Easystats Ltd, London; research assistant, MTA-ELTE Peripato Research Group; gergely.toth@rapporter.net

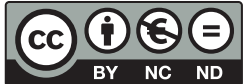


KEYWORDS: spatial filtering, spatial voting turnout, spatial modelling, Budapest

ABSTRACT: One condition of the stable and balanced functioning of democratic systems is the active participation of citizens. Considering the political subsystem, civilian activity is primarily, although not exclusively, manifested in participation at elections.

The relationship between participation in the 2010 parliamentary election and the number of votes cast in favour of the winning party was in the focus of our investigations in this study. According to Klimek et al. (2012), who greatly inspired the current research, conclusions can be drawn about the fairness of the election based on the concentration of votes cast for the winning party. This is possible because salient differences observable in the joint distributions of concentration and participation may suggest problems concerning the fairness of the election. Since the chance of salient differences occurring is negligible, these might suggest manipulation. In our study, we argue that a method which ignores spatial effects may be inefficient in the case of auto-correlated error components because the independence assumption is not met, so this method may lead to biased estimations.

In order to answer the research question, we relied on data derived from voting districts in Budapest which were used to create a geo-referenced spatial point database. Data were entered by voting district, then areal data was created with the help of Voronoi tesselation. In order to shed light on the relationship between participation and the votes cast for the winning party, we relied on spatial filtering as suggested by Getis and Ord, which enables the explicit expression of spatial effects.

The non-parametric Getis spatial filtering has been investigated with the help of optimal distances and first-order topological neighbourhood as well, although the method is primarily based on determining distance-based auto-correlations. The approach which took topological relations into consideration did not result in significant differences in parameter estimates, although it had a somewhat better fit (higher $R^{2}$ and lower AIC value). This calls attention to the problems of applying distance approaches in the case of very unevenly sized irregular configurations.

By the decomposition of variables to spatial and non-spatial components and by the explicit expression of spatial effects, the independence assumption of error components can be fulfilled. As a consequence, it is possible to return to using the traditional Ordinary Least Squares (OLS) method.

The most important finding of our research was that the relationship between voting turnout and votes cast for the winning party in Budapest in 2010 was unjustifiable. Relying on the OLS method and disregarding spatial effects led to serious consequences; it resulted in biased estimations. For this reason, we emphasize the importance of handling auto-correlations properly in the case of spatial data.

\section{Bevezető}

Már Tocqueville és Mill óta ismert gondolat, hogy a demokratikus rendszerek stabil és kiegyensúlyozott működésének egyik alapvető feltétele az állampolgári aktivitás, amely képes az állam túlhatalomra való törekvését korlátozni. E civil tevékenység a politikai alrendszer nézőpontjából elsősorban, de nem kizárólagosan a választásokon való részvételben nyilvánul meg. A választásokon való állampolgári aktivitás egyszerre ok és okozat, amely így a demokratikus társadalmi beágyazottság fontos indikátora (Angelusz, Tardos 2005). 
Ennek megfelelően a választáskutatás egyik fókusza a választásokon való részvétel vizsgálata és többek között annak megértése, hogy a választási rendszerek működésére a participáció milyen tényezőkön keresztül képes befolyással bírni.

Arend Lijphart (1997) ugyanakkor arra hívta fel a figyelmet, hogy egyenlőtlenséget eredményez, ha jelentős számú választói csoport nem, illetve csak alulreprezentált módon vesz részt a döntési folyamatokban. Ebből adódóan könnyen belátható, hogy a különböző társadalmi csoportok szisztematikusan eltérő politikai aktivitásának jellege és kiterjedtsége, a politikai kapcsolathálózati erőforrások további (például gazdasági) előnyök és hátrányok forrásai (Angelusz, Tardos 2005). A politikai erőforrások elosztásának azonban egyértelmű területi vetülete is van. Több empirikus választáskutatás rávilágított arra, hogy eltérő gazdasági fejlettség mellett jellemzően eltérő választói magatartás van jelen, ezért a választási aktivitás elemzésekor megkerülhetetlen a területi szempontok figyelembevétele (Kmetty, Tóth 2011; Tardos 2011).

\section{A tanulmány problémafelvetése}

Az új választójogi törvény következtében felértékelődött az a kérdés, hogy mekkora szavazati aránnyal lehet nyerni egy választókörzetben. A kérdés különösen érdekessé akkor válik, ha feltételezzük, hogy a választási részvétel összefüggésben állhat a győztesre leadott voksok arányával (Klimek, Yegorov, Hanel, Thurner 2012). A tanulmányunkat inspiráló írás (Klimek, Yegorov, Hanel, Thurner 2012) szerint a győztesre leadott szavazatok koncentráltságából következtetni lehet a választások tisztaságára, mivel a koncentráltág és a részvétel együttes eloszlásaiban megfigyelhető kiugró értékek a választások tisztaságával kapcsolatos aggályokat vethetnek fel. A kiugró értékek ugyanis csak elenyésző valószínűséggel tulajdoníthatóak a véletlennek, ezért valamiféle manipulációra utalhatnak. Folytonos változók együttes eloszlásának ábrázolásának hatékony módszere a kétdimenziós hisztogram, amely lényegében a véletlen fluktuációk elsimítása után kapott szórásdiagram. Mivel a véletlen ingadozások a kétdimenziós hisztogramon el vannak simítva, az esetleges kiugró értékek könnyen azonosíthatók. Véleményünk szerint e naiv, a térbeli hatásokat nélkülöző módszer a hibatagok autokorreláltsága esetén a függetlenségi feltevés hiánya miatt nem megfelelő, torzított becslésekhez vezethet.

Tanulmányunkban arra vállalkozunk, hogy a térbeli autoregresszivitás segítségével módszertanilag árnyaltabb módon vizsgáljuk meg, hogy a győztesre adott szavazatok száma milyen összefüggésben állhat a részvételi arányokkal. Ehhez a választókerületnél alacsonyabb szintű szavazókörönkénti adatokra támaszkodunk. 


\section{Az adatok}

Adatbázisunk a főváros 2010-es országgyülési választások első fordulójának szavazókörönkénti adatait tartalmazza. Az adatokat az Országos Választási Iroda honlapjáról (http://valasztas.hu) gyűjtöttük.

A szavazókörök száma Budapesten 1605 volt (a részleteket az 1. táblázat tartalmazza). Az adatbázis valamennyi szavazókör részvételi adatait, valamint a pártokra leadott voksokat tartalmazza (a továbbiakban ezt nem térbeli adatbázisnak nevezzük).

Fontos utalnunk a külképviseleti szavazatok problémájára. A külképviseleteken leadott voksokat választókerületenként egy-egy szavazókörhöz adták hozzá. Ezek általában 100 fővel növelték az adott körzetben a szavazásra jogosultak számát (maximum 359, minimum 27 fö). Budapesten összesen 2990 ilyen szavazatról van szó, amely a leadott voksok mindössze 0,3\%-át tette ki. A választási részvétel meghatározásához lehetséges e szavazatok leválasztása, a pártokra leadott voksok esetében viszont nem. Elképzelhető, hogy a külképviseleteken leadott szavazatok tartalmaznak önszelekciót, vagyis a külképviseleten szavazók részvételi szándéka erősebb, pártpreferenciájuk pedig eltér a véletlentől. Feltételezésünk szerint ez a torzítás a külképviseleti szavazatok súlyánál fogva nem meghatározó.

A szavazókörök geokódolását az R program és az XML csomag segítségével a GoogleMaps Geocoding API-jával végeztük. ${ }^{1}$ A szavazókörökhöz tartozó címeket egyesével elküldtük a Google szervereinek, majd a kapott XML találati listát feldolgoztuk, és abból azokat a címeket vettük figyelembe, amelyek az adott településhez tartoztak. (Erre a szürésre azért volt szükség, mert a szolgáltatás ismeretlen utca esetén a legközelebbi, hasonló nevű közterülettel bíró település koordinátáit adja vissza.) A Geocoding API minden esetben megadta a helyek pontosságát is. A valasztas.hu oldalról a szavazóköri eredményeken kívül letöltöttük az adott szavazókörhöz tartozó közterületek listáját, majd abból mintát véve, a kapott koordináták számtani átlaga adta a becsült geokódot. Erre az eljárásra azért volt szükség, mert a szavazókörök címlistája sokszor geokódolásra alkalmatlan (pl. az intézmények rövidített neveit tartalmazza), másfelől így lehetőségünk nyílt a szavazókörök geometriai középpontját meghatározni a szavazó-

1. táblázat: A 2010. évi országgyűlési választások 1. fordulójának részvételi adatai Budapesten Participation figures of the first round of general elections 2010 in Budapest

\begin{tabular}{lr}
\hline \multicolumn{1}{c}{ Megnevezés } & \multicolumn{1}{c}{$N$} \\
\hline Szavazókörök száma & 1605 \\
Országos egyéni választókerületek száma & 32 \\
A névjegyzékben szereplő választópolgárok száma & 1356508 \\
$\quad$ ebből: külképviseleti választópolgárok száma & 3661 \\
Szavazóként megjelent választópolgárok száma & 949780 \\
ebből: külképviseleteken leadott szavazatok száma & 2900 \\
\hline
\end{tabular}

Forrás: http://valasztas.hu 
helyiségek koordinátái helyett. Számos esetben különböző szavazókörök szavazóhelységei ugyanazon épületben találhatók. Ezekben az esetekben aggregáltuk a megfigyeléseinket, így számottevően csökkent az adatpontok száma. A valasztas.hu honlapon szereplő elnevezések ugyanazon cím esetében is tartalmaznak kisebb eltéréseket, ezek túlnyomórészt a szóközök, hosszú és rövid magánhangzók, valamint rövidítések eltérő használatából adódnak. Az aggregálást megelőzően a rekordok tisztítását manuálisan végeztük el. Az összevonásokat követően Budapesten 600 adatpontot különítettünk el (ezt nevezzük a továbbiakban térbeli adatbázisnak). A két adatbázis fontosabb leíró ismérveit a 2. táblázatban közöljük.

A geokódolás után az adatokat Voronoj-diagram segítségével ábrázoltuk (1. ábra), ami lehetővé tette a pontalakzatok szomszédsági struktúrájának feltérképezését, ez pedig a térbeli elemzés miatt kulcsfontosságú. Ismereteink szerint a hazai területi választáskutatás hasonló mélységű adatokat eddig nem jelenített meg és nem elemzett. A Voronoj-diagram alkalmazását az tette szükségessé, hogy a szavazókörök térképe nem állt rendelkezésünkre.

Az elemzésbe bevont változók mindegyike azonos mértékben, erősen szignifikánsan területileg autokorrelált. A választási részvétel a föváros budai oldalán magasabb volt, mint a pesti oldalon. Ez az eredmény megegyezik korábbi vizsgálatunkkal, amely a választási részvétel és a terület ökológiai státusza (munkanélkülisége és jövedelem-színvonala) között talált pozitív összefüggést (Bálint, Bozsonyi 2011, 2012). A győztesre leadott voksok esetében ez a szabályszerűség már kevésbé nyilvánvaló.

2. táblázat: A választási adatbázisok leíró statisztikái Descriptive statistics of electional data

\begin{tabular}{lcccc}
\hline \multirow{2}{*}{\begin{tabular}{c} 
Statisztikák \\
\cline { 2 - 5 }
\end{tabular}} & \multicolumn{2}{c}{ Nem térbeli adatbázis } & \multicolumn{2}{c}{ Térbeli adatbázis } \\
\cline { 2 - 5 } & $\begin{array}{c}\text { Részvételi arány } \\
\text { (\%) }\end{array}$ & $\begin{array}{c}\text { Gyöztes pártra } \\
\text { adott szavazatok } \\
\text { aránya }(\%)\end{array}$ & $\begin{array}{c}\text { Részételi arány } \\
(\%)\end{array}$ & $\begin{array}{c}\text { Gyöztes pártra } \\
\text { adott szavazatok } \\
\text { aránya (\%) }\end{array}$ \\
\hline Minimum & 25,71 & 31,89 & 25,71 & 34,42 \\
Maximum & 85,84 & 64,23 & 84,03 & 69,13 \\
Terjedelem & 60,13 & 32,34 & 58,32 & 34,70 \\
Átlag & 69,50 & 45,99 & 69,41 & 46,39 \\
Medián & 70,44 & 45,53 & 70,42 & 45,83 \\
Szórás & 7,47 & 5,39 & 7,34 & 5,00 \\
Variancia & 55,83 & 29,05 & 53,90 & 25,02 \\
Ferdeség & $-0,89$ & 0,27 & $-1,16$ & 0,42 \\
Csúcsosság & 1,81 & $-0,21$ & 3,32 & 0,27 \\
Kolmogorov-Szmirnov-próba & 2,21 & 1,46 & 1,45 & 1,19 \\
Szignifikancia (kétoldalú p)* & 0,00 & 0,03 & 0,03 & 0,17 \\
N & 1605 & 1605 & 600 & 600 \\
\hline
\end{tabular}

*Ahol p<0,05 ott az eloszlás eltérése a normalitástól szignifikánsnak tekintheto".

Forrás: http://valasztas.hu 
1. ábra: A részvételi arány (balra) és a győztes pártra leadott szavazatok aránya (jobbra) a 2010. évi országgyủlési választások 1 . fordulójában, a fővárosi szavazókörökben Participation ratio (left) and ratio of voters of the winning party (right) in the first round of general elections 2010 in Budapest
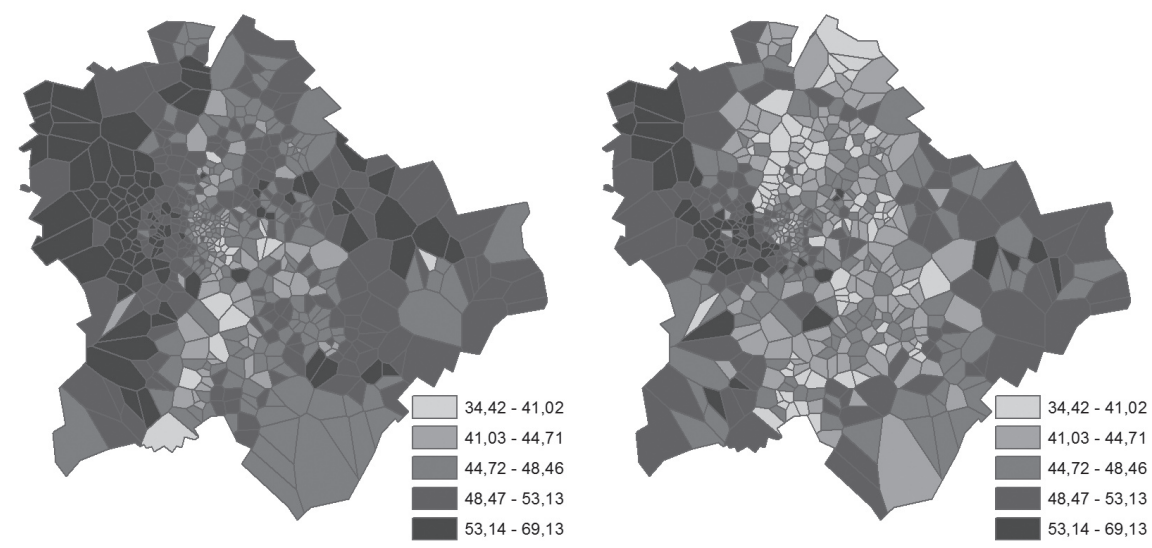

Megjegyzés: A Moran-féle I értéke a részvételi aránynál 0,540 ( $p<0,001)$, a győztes pártra leadott szavazatok arányánál 0,550 ( $p<0,001)$.

\section{Nemparaméteres térbeli szürés}

A nemparaméteres térbeli szürés módszerének kidolgozása Getis és Ord nevéhez kötődik. Az eljárás a modellbe bevont, térben autokorrelált változókat két összetevőre bontja. Az egyik a térbelileg szűrt változó, amely már nem tartalmaz térbeli hatást, a másik pedig a térbeli komponens, amely az eredeti változókba ágyazott térbeli hatást hordozza. A változókészlet tagjainak egyenkénti átalakítása lehetővé teszi a legkisebb négyzetek módszerével történő regressziós becslést, valamint elkülöníti a térbeli függőséget, amelynek mint látens kapcsolatnak önálló szerepe lehet a modell értelmezésében.

A szürés többlépcsős eljárás. Az első lépésben annak vizsgálata szükséges, hogy a térbeli autokorreláció jelen van-e az adatokban. Amennyiben igen, a változóról le kell választanunk a térbeli komponenst. A szürés a Getis és Ord (1992) által alkalmazott lokális $G_{i}$ statisztikán alapul. A vizsgált terület térelemekből épül fel. Valamennyi megfigyelést egyetlen ponttal azonosítunk, ezek Descartes-féle planimetrikus koordinátái (a mi esetünkben az egységes országos vetületi koordinátái) ismertek. Vizsgáljuk az i hely és a tőle d távolságra található térelemek értékei közötti kapcsolatot! $A G_{i}(d)$ mutatószám az alábbi módon határozható meg az X változó i-edik pontjára (Getis 1995): 


$$
G_{i}(d)=\frac{\sum_{j=1}^{n} w_{i j}(d) x_{j}}{\sum_{j=1}^{n} x_{j}}, j \neq i,
$$

ahol $\mathrm{w}_{\mathrm{ij}}$ szimmetrikus térbeli súlymátrix, amelyet a megfigyelések euklideszi távolságmátrixából hozunk létre. A mátrix elemeinek értéke 1, ha azok az általunk meghatározott d távolságon belül helyezkednek el, ekkor szomszédosnak tekintjük őket, minden más esetben 0 értéket vesznek fel. A mátrix e típusában adott pont önmagával nem szomszédos, a súlymátrix főátlójában 0 értékek szerepelnek. Az egyenlet számlálójában az i-edik ponttól d távolságra található pontok összege, a nevezőben pedig valamennyi megfigyelés értékének összege szerepel. A hányados számlálója és nevezője sem tartalmazza $x_{i}$ értékét. $G_{i}(d)$ az adatpontok súlyozásával méri a térbeli összefüggés erősségét. A mutató értékkészlete 0 és 1 között van. A d távolságon belül átlag feletti értékek tömörülése esetén $G_{i}$ értéke magas lesz, az alacsony értékek koncentrálódása esetén alacsony. A mutató szignifikanciaszintjét a standardizált értékből határozzuk meg. A z érték szórásegységekben mutatja meg az i-edik megfigyelés eltérését a „minta” átlagától. Ehhez ismernünk kell a mutató várható értékét és szórását. A várható érték a következőképpen határozható meg:

$$
\mathrm{E}\left(\mathrm{G}_{\mathrm{i}}\right)=\frac{\mathrm{W}_{\mathrm{i}}}{(\mathrm{n}-1)} \text {, ahol } \mathrm{W}_{\mathrm{i}}=\sum_{\mathrm{j}=1}^{1} \mathrm{w}_{\mathrm{ij}}(\mathrm{d}) \quad \mathrm{i} \neq \mathrm{j} .
$$

A mutató varianciájához definiálnunk kell:

$$
Y_{i 1}=\frac{\sum_{j=1}^{n} x_{j}}{n-1} \text { és } Y_{i 2}=\frac{\sum_{j=1}^{n} x_{j}^{2}}{n-1}-Y_{i 1}^{2}, i \neq j .
$$

A variancia ezután a következő képlettel számítható:

$$
\operatorname{Var}\left(G_{i}\right)=\frac{W_{i}\left(n-1-W_{i}\right)}{(n-1)^{2}(n-2)}\left(\frac{Y_{i 2}}{Y_{i 1}^{2}}\right) .
$$

A $G_{i}$ megfigyelt és várható értéke közötti különbség választ ad arra a kérdésre, hogy a változó magas vagy alacsony értékének csoportosulása jellemző az adott hely környezetében. Feltételezve, hogy $G_{i}$ normáleloszlást követ, a standardizált érték meghatározható:

$$
\mathrm{Z}_{\mathrm{i}}=\frac{\mathrm{G}_{\mathrm{i}}(\mathrm{d})-\mathrm{E}\left[\mathrm{G}_{\mathrm{i}}(\mathrm{d})\right]}{\sqrt{\operatorname{Var}\left(\mathrm{G}_{\mathrm{i}}(\mathrm{d})\right)}} .
$$

A szürés során a feladat $Z$ változó értékének valamennyi i helyen történő felbontása a térbeli hatás nélküli $\left(\mathrm{x}^{\mathrm{f}}\right)$ és a térbeli hatást tartalmazó összetevőre $\left(\mathrm{x}^{\mathrm{s}}\right)$. A térbeli függetlenség mértékét $\mathrm{E}\left(\mathrm{G}_{\mathrm{i}}(\mathrm{d})\right)$ mutatja. Ha a várható és a megfigyelt érték között nincs különbség, akkor azt mondhatjuk, hogy az i ponttól d távolságra elhelyezkedő pontokhoz tartozó értékek egymástól függetlenek, azaz nem autokorreláltak, ennek megfelelően szürésre sincs szükség. Egyéb esetben a megfigyelt és a várható érték eltér egymástól (függetlenül attól, hogy e különbség szignifikáns-e). Ha $\mathrm{G}_{\mathrm{i}}$ értéke magasabb, mint annak várható értéke, akkor a különbség a megfigyelt érték és a térbelileg szűrt érték között pozitív lesz, utalva a magas értékek autokorreláltságára. $\mathrm{Ha}_{\mathrm{i}}$ alacsony, a különbség a 
megfigyelt és a térbelileg szűrt érték között negatív lesz, jelezve az alacsony változóértékek adott pont körüli csoportosulását. A korrelálatlan, térbeli hatástól független rész képlete a következő:

$$
x_{i}^{f}=x_{i} \frac{E\left(G_{i}\right)}{G_{i}} .
$$

A különbség az eredeti változó $(\mathrm{x})$ és a térbelileg szűrt változó $\left(\mathrm{x}^{\mathrm{f}}\right)$ között az új, térbeli hatást tartalmazó magyarázó változó $\left(\mathrm{x}^{\mathrm{s}}\right)$ :

$$
\mathrm{x}_{\mathrm{i}}=\mathrm{x}_{\mathrm{i}}^{\mathrm{f}}+\mathrm{x}_{\mathrm{i}}^{\mathrm{s}} \text {. }
$$

Ord és Getis (2001), valamint Getis (1995) hangsúlyozzák, hogy a szűrést minden autokorrelált változóra az optimális távolság függvényében egyedileg kell elvégezni. A szürést követően - tehát miután a változók térbeli hatását elkülönítettük - beléptethetjük a változókat a regressziós modellbe. Megfelelő távolság és az előfeltevések teljesülése mellett kivitelezett szűrésnél a hibatagok függetlensége miatt a legkisebb négyzetek módszerével történő becslés alkalmazásának nincs akadálya.

A nemparametrikus Getis-féle térbeli szürést az optimális távolsággal és az elsődleges topológiai szomszédsággal is vizsgáltuk. A Getis-féle módszer az autokorreláció távolságalapú meghatározásán alapul. Az eljárás feltételezi, hogy valamennyi megfigyelés rendelkezik legalább egy szomszéddal. E feltétel hiányában megoldás lehet a szomszédsággal nem rendelkező pontok figyelmen kívül hagyása, az autokorreláltság szomszédság nélküli elemek kihagyásával történő meghatározása. Ez a lehetőség értelemszerüen nem kielégítő, ha az elemzés megfigyelések egészére vonatkozik. Az általunk vizsgált szavazóköri adatokban a minimális távolság, amely mellett a szomszédsági kritérium teljesült 2176,2 méter volt. Azonban a térbeli szüréshez önmagában a minimális távolság meghatározása nem elégséges, hiszen annak valódi sarokköve az optimális távolság meghatározása. Getis és Ord (1992) az általános G statisztika alkalmazását javasolták, keresve azt a távolságot, amelynél már nem érzékelhető autokorreláció. Ehhez hasonlatos geostatisztikai megoldás lehet a változónkénti szemivariogram alkalmazása (Getis, Griffith 2002). Ferstl (2007a) a Moran-indexre támaszkodva választotta ki azt a távolsági paramétert, amely mellett a szűrt változó hordozta autokorreláció minimálisra csökkent. Szintén a Moran-féle I előnyös tulajdonságára hagyatkozott Battisti és Di Vaio (2009). Ők a még szignifikáns minimális Moran mutatóval rendelkező távolságot tartották megfelelőnek, elméleti megfontolásuk szerint ezen érték a térbeli túlcsordulás (spillover) határértéke.

Jelen tanulmányban a globális (általános) G mutatóból indultunk ki, ennek standardizált értékeit 100 méteres lépésekkel haladva 2200 métertől 5000 méterig határoztuk meg, keresve azt az értéket, amelynél az autokorreláltság maximális. A globális $\mathrm{G}$ statisztika meghatározható az alábbi képlettel (Getis, Ord 1992):

$$
\mathrm{G}_{(\mathrm{d})}=\frac{\sum_{\mathrm{i}=1}^{\mathrm{n}} \sum_{\mathrm{j}=1}^{\mathrm{n}} \mathrm{w}_{\mathrm{ij}} \mathrm{x}_{\mathrm{i}} \mathrm{x}_{\mathrm{j}}}{\sum_{\mathrm{i}=1}^{\mathrm{n}} \sum_{\mathrm{j}=1}^{\mathrm{n}} \mathrm{x}_{\mathrm{i}} \mathrm{x}_{\mathrm{j}}}, \quad \forall \mathrm{j} \neq \mathrm{i},
$$


ahol $\mathrm{x}_{\mathrm{i}}$ a vizsgált változó értéke $\mathrm{i}$ helyen, $\mathrm{x}_{\mathrm{j}}$ a változó $\mathrm{j}$ helyen megfigyelt értéke, $\mathrm{w}_{\mathrm{ij}}$ a szomszédsági kapcsolatokat rögzítő szimmetrikus súlymátrix. A mátrix elemeinek értéke 1 , ha két megfigyelési egység d távolságon belül helyezkedik el, és 0 , ha nem. Továbbá definíció szerint a megfigyelések nem szomszédjaik önmaguknak. Az általános $\mathrm{G}$ mutatóval a térbeli koncentrációt teszteljük.

A G mutató általános tulajdonságai között említhető, hogy skálafüggetlen, de nem helyfüggetlen. Alkalmazásának korlátját jelenti, hogy csak természetes számokra alkalmazható. Hasonlóan más statisztikákhoz, a logaritmikus transzformáció módosítja a mutató értékét (Getis, Ord 1992).

A mutató standardizált értéke meghatározható a megfigyelt és a várható érték, valamint a megfigyelt érték varianciájának ismeretében:

$$
\mathrm{Z}_{\mathrm{G}}=\frac{\mathrm{G}-\mathrm{E}[\mathrm{G}]}{\sqrt{\mathrm{V}[\mathrm{G}]}}, \text { ahol } \mathrm{E}[\mathrm{G}]=\frac{\sum_{\mathrm{i}=1}^{\mathrm{n}} \sum_{\mathrm{j}=1}^{\mathrm{n}} \mathrm{w}_{\mathrm{ij}}}{\mathrm{n}(\mathrm{n}-1)}, \forall_{\mathrm{j}} \neq 1 ; \mathrm{V}[\mathrm{G}]=\mathrm{E}\left[\mathrm{G}^{2}\right]-\mathrm{E}[\mathrm{G}]^{2} .
$$

Ha az általános $G$ teszt nullhipotézise szerint definiált távolságon belül nincs térbeli autokorreláltság, akkor a megfigyeléseket függetlennek tekinthetjük. Magas Z és alacsony p értékek esetében a nullhipotézist elvethetjük. A statisztikai következtetés történhet a standard normalitási feltevés mellett (ebben az esetben a kevés számú szomszéd a p érték megbízhatóságát megkérdőjelezi), vagy Monte Carlo-eljárás segítségével. A G mutató nem csupán a térbeli csoportosulás mértékére mutat rá, hanem annak típusára is. A pozitív Z értékek magas változóértékek csoportosulására utalnak, a negatív Z értékek pedig az alacsonyak térbeli halmozódására.

\section{Eredmények}

A győztes pártra leadott szavazatok (WINNER) G értéke minden esetben pozitív volt, utalva a térbeli struktúrát jellemző magas értékek csoportosulására. A magyarázó változó, azaz a választási részvétel értéke valamennyi sávszélesség mellett negatív volt, ami az alacsonyabb értékek csoportosulására utal. A standardizált $\mathrm{Z}(\mathrm{G})$ abszolút értékei alapján a győztes pártra leadott voksok arányának autokorreláltsága 2200 és 3200 méteres sávszélességnél mutatott magasabb értéket, és e távolságoknál is legfeljebb 10\%-os szinten szignifikáns autokorrelációt tapasztalhattunk (2. ábra). A Moran-féle I alapján az autokorreláció 2200 méternél volt a legmagasabb és erősen szignifikáns (3. táblázat). A választási részvétel (TURNOUT) esetében a standardizált $Z$ értékek mérsékelt eltérést mutattak a távolságok függvényében. A konfidencia-intervallumok alapján ezek valószínűleg nem bizonyulnának szignifikáns eltérésnek. Körülbelül 4000 méteres távolságig mérsékelt csökkenést figyelhetünk meg, azt követően visszafogott emelkedést. A globális autokorreláció különböző távolságok melletti alakulását vizsgálva végül mindkét változónál 2200 méterben határoztuk meg a térbeli szüréshez alapul vett távolságot. Az elemzést vezérszomszédságon ala- 
2. ábra: A globális $\mathrm{G}$ mutató (standardizált abszolút értékek), 100 méteres lépésekben

Values of global $G$ index (standardized absolute values), by steps of 100 meters

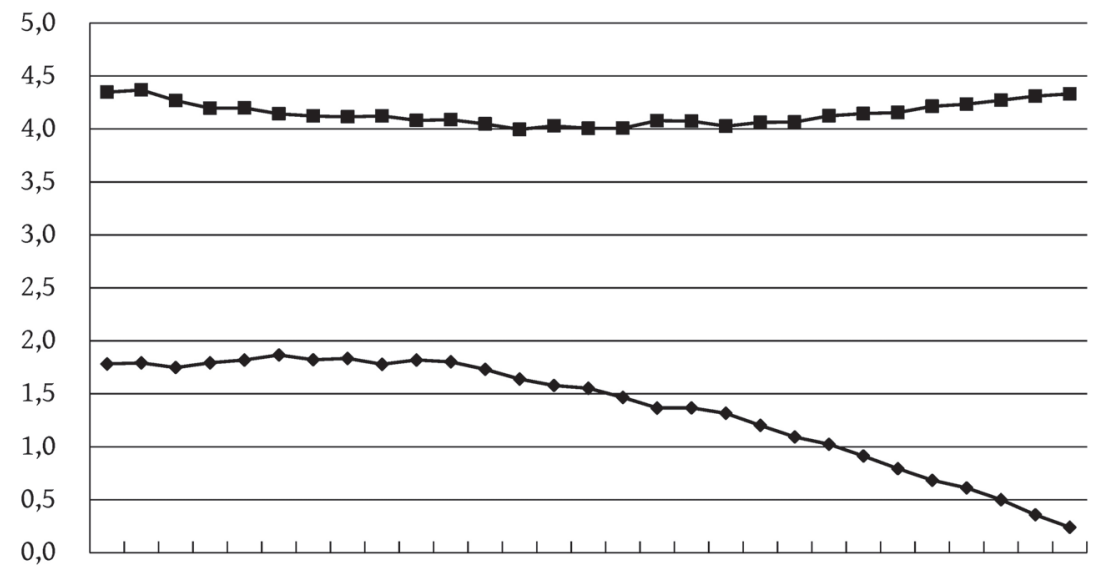

220024002600280030003200340036003800400042004400460048005000

$\mathrm{m}$

$\rightarrow Z(G)$ WINNER $\rightarrow$-Z(G) TURNOUT

puló bináris súlymátrix segítségével végeztük el. Ebben az esetben a súlyok összege a szomszédok számával egyezik meg (a súlymátrixokról részletesebben lásd pl. Bivand, Pebesma, Gómez-Rubio 2013b):

$$
\mathrm{w}_{\mathrm{ij}}(\mathrm{d})=0 \text {, ha } \mathrm{i}=\mathrm{j} ; \mathrm{w}_{\mathrm{ij}}(\mathrm{d})=1 \text {, ha } \mathrm{d}_{\mathrm{ij}} \leq 2200 ; \mathrm{w}_{\mathrm{ij}}(\mathrm{d})=0 \text { ha } \mathrm{d}_{\mathrm{ij}}>2200 \text {. }
$$

A távolságalapú szomszédság főképp olyan térbeli struktúráknál használható, ahol a pontok közötti távolság viszonylag egyenletes. Szabálytalanabb poligonok esetében nem a leghatékonyabb megoldás, mivel így a választási magatartás szempontjából irreleváns kapcsolatok is megjelenhetnek. Esetünkben - érvényesítve a minimális szomszédsági követelményt - a külső kerületek szavazókörei közötti jelentősebb távolság alakíthat ki egyenlőtlen szomszédsági kapcsolatrendszert. A 2200 méteres sugár mellett a megfigyelések átlagosan 39,15 szomszéddal rendelkeztek, az összes lehetséges kapcsolatból (359 400) a tényleges kapcsolatok száma 23488 volt (6,52\%). ${ }^{2}$ Két pont 115 kapcsolattal rendelkezett, ezek elhelyezkedésükből fakadóan a megfigyelések ötödével $(19,2 \%)$ kerültek szomszédságba. Tapasztalataink szerint a sugaras és izotróp távolságok használatához képest a maximális térbeli hatás más típusú kapcsolatrendszer mellett érvényesülhet (Bálint, Bozsonyi 2012), ezért a szürést a szakirodalmi gyakorlattól eltérően topológiai szomszédsággal (vezérszomszédság) is elvégeztük, és az eredményeket összehasonlító módon közöljük.

A térbeli szűrés során a függő és a független változót térbeli hatástól független (szürt) és a térbeli hatást tartalmazó komponensre bontottuk (3. táblázat), 
3. táblázat: A változók autokorreláltsága

Autocorrelation between variables

\begin{tabular}{lcccccc}
\hline \multirow{2}{*}{ Változó } & \multicolumn{3}{c}{ Távolságalapú $(\mathrm{d}=2200 \mathrm{~m})$} & \multicolumn{3}{c}{ Elsörendü vezérszomszédság } \\
\cline { 2 - 7 } & Moran I & $Z(\mathrm{I})$ & $p$ & Moran I & $Z(\mathrm{I})$ & $p$ \\
\hline WINNER & 0,371 & 43,899 & 0,000 & 0,550 & 23,229 & 0,000 \\
WINNER (szürt) & 0,001 & 0,331 & 0,370 & $-0,195$ & $-8,163$ & 1,000 \\
WINNER (térbeli) & 0,645 & 76,769 & 0,000 & 0,855 & 36.072 & 0,000 \\
\hline TURNOUT & 0,425 & 50,432 & 0,000 & 0,540 & 22,864 & 0,000 \\
TURNOUT (szürt) & $-0,037$ & $-2,496$ & 0,994 & $-0,190$ & $-7,975$ & 1,000 \\
TURNOUT (térbeli) & 0,752 & 88,817 & 0,000 & 0,833 & 35,133 & 0,000 \\
\hline
\end{tabular}

autokorreláltságuk ellenőrzésére a térbeli komponensnél előforduló negatív értékek miatt Moran-indexszel került sor:

$$
I=\frac{n}{\sum_{i=1}^{n} \sum_{j=1}^{n} w_{i j}} \frac{\sum_{i=1}^{n} \sum_{j=1}^{n} w_{i j}\left(x_{i}-\bar{x}\right)\left(x_{j}-\bar{x}\right)}{\sum_{i=1}^{n}\left(x_{i}-\bar{x}\right)^{2}},
$$

ahol $\mathrm{n}$ a megfigyelések száma, $\mathrm{x}_{\mathrm{i}}$ az $\mathrm{X}$ változó értéke $\mathrm{i}$ és $\mathrm{j}$ helyen, $\mathrm{w}_{\mathrm{ij}}$ a területi súlymátrix. A felbontás eredményeképpen a térmentes változók autokorreláltsága minden esetben inszignifikáns lett. ${ }^{3}$

A legkisebb négyzetek módszerével becsült regressziós modellek (4. táblázat) a választási részvétel szignifikáns hatására mutattak rá, mind a geokódolt, mind pedig a nem térbeli adatbázis alapján (1-2. modellek). A hibatagok függetlenségének feltevése nem teljesült, a reziduumok autokorreláltsága számottevő (Moran $I=0,466, p<0,001)$. A Getis-Ord-típusú szüréssel a magyarázó változó felbontása a hibatagok autokorrelációját csekély mértékben csökken-

4. táblázat: A regressziós modellek eredményei

Results of regression models

\begin{tabular}{lccccc}
\hline \multirow{2}{*}{ Változók } & \multicolumn{2}{c}{ Legkisebb négyzetek módszere } & \multicolumn{3}{c}{ Getis-Ord-féle térbeli szürés } \\
\cline { 2 - 6 } & 1. modell & 2. modell & 3. modell & 4. modell $^{c}$ & 5. modell \\
\hline Konstans & $32,93^{* * *}$ & $31,77^{* * *}$ & $43,51^{* * *}$ & $46,00^{* * *}$ & $46,77^{* * *}$ \\
TURNOUT & $0,19^{* * *}$ & $0,21^{* *}$ & & & \\
TURNOUT szürt & & & 0,04 & 0,01 & $-0,01$ \\
TURNOUT térbeli & & & $0,50^{* * *}$ & 0,06 & 0,04 \\
WINNER térbeli & & & & $1,01^{* * *}$ & $0,92^{* * *}$ \\
\hline Korrigált $\mathrm{R}^{2}$ & 0,07 & 0,09 & 0,19 & 0,45 & 0,54 \\
Akaike & 9872,06 & 3579,28 & 3511,78 & 3287,45 & 3179,93 \\
Moran I & n.a. & $0,46^{* * *}$ & $0,33^{* * *}$ & $-0,01$ & $-0,17$ \\
$\mathrm{~N}$ & 1605 & 600 & 600 & 600 & 600 \\
\hline
\end{tabular}

*** $p<0,001,{ }^{* *} p<0,01,{ }^{*} p<0,05$

a) nem térbeli adatbázis, b) térbeli adatbázis, c) távolságalapú szürés, a hibatagok autokorreláltságának ellenőrzése távolságalapú súlymátrixszal történt $(d=2200 \mathrm{~m}), d$ ) topológiai kapcsolatokon alapuló szürés, a hibatagok autokorreláltságának ellenőrzése elsőrrendü vezérszomszédsággal történt. 
3. ábra: A győztes pártra leadott szavazatok arányának térbeli komponense Spatial component of ratio of voters of winning party

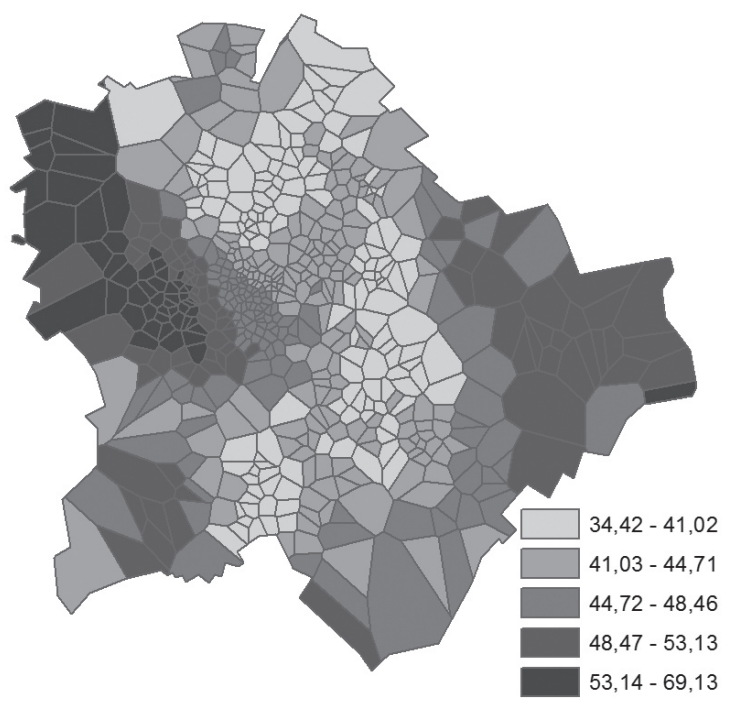

tette, amit végül az eredményváltozó térbeli komponensének bevonásával sikerült eltüntetnünk (3. ábra).

A kibővített modellben a részvételi változó térbeli tagja is inszignifikánssá vált. Mindez arra utal, hogy a részvételi változó térbeli hatását a függő változó térbeli hatása foglalta magába (3. ábra).

Habár a Getis-Ord-féle szürés távolságalapú megközelítés, a vezérszomszédsággal végzett számítások a paraméterbecslésekben lényeges különbségeket nem hoztak. Az ilyen módon szürt modell illeszkedése azonban jobbnak bizonyult (magasabb korrigált $\mathrm{R}^{2}$ és alacsonyabb Akaike-érték), ami a távolsági megközelítés problémáira hívja fel a figyelmet az eltérő nagyságú térbeli alakzatok esetében.

\section{Módszertani következtetések}

Tanulmányunkban a 2010. évi országgyűlési választások fővárosi eredményeit térbelileg elemeztük. Ennek első lépéseként nyilvánosan elérhető adatbázisból származó adatok geokódolását végeztük el és létrehoztunk egy kvantitatív geográfiai módszerekkel elemezhető adatbázist. Célunk az volt, hogy a lehető legalacsonyabb területi szinten vizsgáljuk a megfigyelések függetlenségével kapcsolatos feltevés meghiúsulásának következményeit. Ehhez a térbeli szűrés legegyszerủbb, nemparaméteres módszerét alkalmaztuk. A módszer előnye ab- 
ban rejlik, hogy a változók felbontásával lehetővé válik a térbeli és az önálló (tartalmi) hatás meghatározása. E tulajdonság különösen előnyös összetett jelenségek vizsgálatakor. Tanulmányunkban a győztes pártra adott voksok arányát és a választási részvétel arányát elemeztük. A nem térbeli megközelítések (függetlenül az adatbázis típusától) a választási részvétel mérsékelt, de szignifikáns hatását mutatták ki. A megfelelő térbeli megközelítés ennek a hatásnak a hamis voltára világított rá. A hibatagok autokorreláltsága miatt a felbontott magyarázó változó mellett szükség volt az eredményváltozó térbeli hatásának a modellbe építésére is. A mind a távolságalapú, mind a vezérszomszédságot használó modellek a függő változó térbeli összetevőjének megkerülhetetlen szerepét támasztották alá. A tanulmány jellegéből fakadóan nagyon takarékos változókészlet (mindössze egyetlen változó) felveti a modell szempontjából problematikus, kihagyott változó okozta torzítás lehetőségét (Gujarati 2003), vagyis elképzelhető, hogy más, a kérdéskör szempontjából releváns változó a térbeli hatást számottevően módosította volna. Az általunk alkalmazott területi léptéken tapasztalt erős térbeli hatás a megfelelő módszer alkalmazásának a szükségességére hívja fel a figyelmet. Ennek hiányában szinte garantált a rosszul illeszkedő modellek felállítása, súlyosabb esetben a torzított becslésekből fogant tévkövetkeztetések megfogalmazása. Az előzetes várakozásoktól és a térbeli hatásokat nem kezelő modellek eredményeitől eltérően azt kaptuk, hogy a győztesre leadott szavazatok aránya közvetlenül nem függ a részvételi aránytól, viszont erősen függ a térbeliségtől, méghozzá az eredményváltozó térbeli összetevőjétől, azaz részben önmagától.

Bármi is legyen a térbeli hasonlóság mögötti oksági kapcsolat, a térbeliség erős szerepe jelzi a választási előrejelzésekben a standard közvélemény-kutatói módszertan határait. Az erős szignifikáns pozitív autokorreláció jelenléte a választási adatokban arra enged következtetni, hogy a társadalmi-gazdasági kontextus sokat számít az emberi magatartások, döntések világában. A választók nem triviális eloszlása a térben új kihívások elé állítja a reprezentatív minták tervezését és a belőlük való következtetések elméletét.

Megfogalmazhatunk néhány észrevételt a Klimek, Yegorov, Hanel és Thurner (2012) által alkalmazott, a térbeliséget figyelmen kívül hagyó naiv módszertanról is. Eredményeiket ugyanis némileg kérdésessé teszik kétdimenziós hisztogramjaink (4. ábra).

Mint látható, a szignifikáns térbeli modell következtében az eredeti kétdimenziós hisztogram (jobb oldalt fent) erősen eltér a térbeli hatásoktól tisztított hisztogramtól. Így Klimek és szerzőtársainak véleményétől eltérően arra következtetünk, hogy a térbeli hatások figyelembevétele nélkül illesztett hisztogram torzít, éppen ezért a különböző választások térbeli összehasonlítására is alkalmatlan, hiszen nem tudjuk, hogy a különböző választások hisztogramjai közötti eltérést a koncentrációs folyamat maga vagy a térbeli beágyazódás eltérő mintázata okozta. 
4. ábra: A választói részvétel és a győztes pártra leadott voksok kétdimenziós hisztogramjai Histograms of voter turnout and voters of winning party

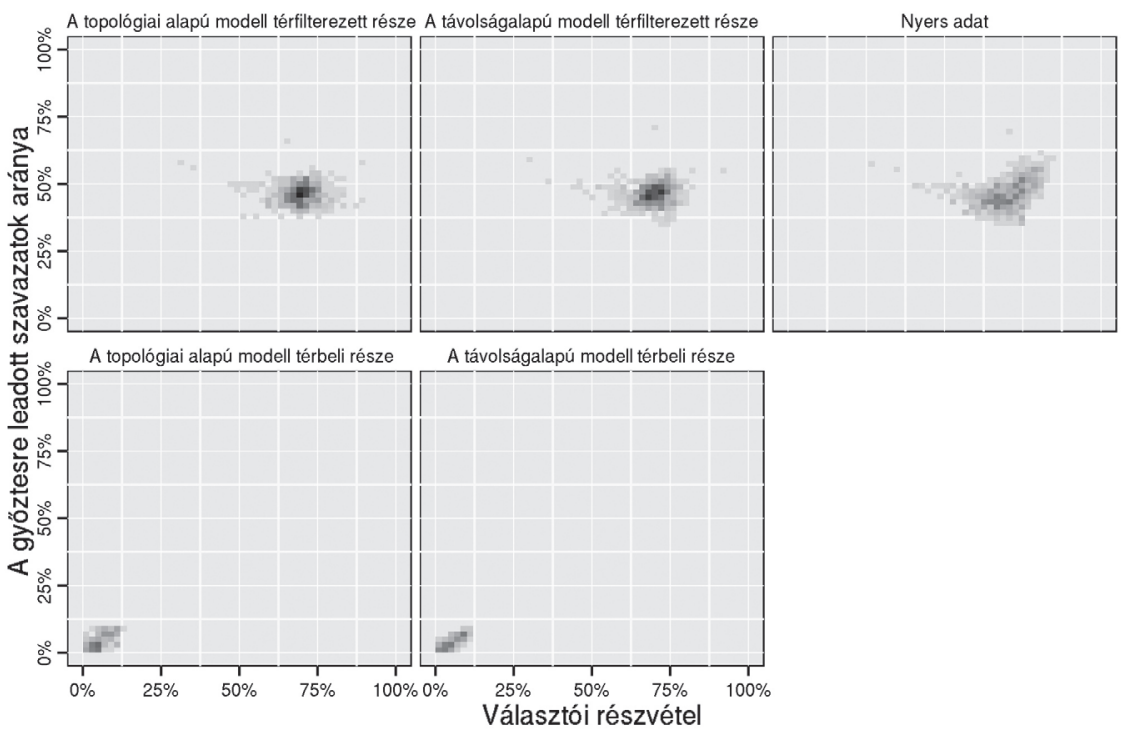

\section{Elméleti következtetések}

A területi adatokon alapuló hazai választáskutatás számos atlaszt, monográfiát (Hubai 2001; Mészáros, Szakadát 1998), adatbázist (vokscentrum.hu) tudhat maga mögött. A hazai tanulmányok túlnyomó része főképp a térbeli politikai mintázatok és törésvonalak leírására, a választási eredmények tagoltságának bemutatására szorítkozik (Bódi, Bódi 2011; Hajdú 2006; Kovacs, Dingsdale 1998; Martis, Kovacs, Kovacs, Peter 1992; Mészáros, Solymosi, Speiser 2007).

Tanulmányunk megírását alapvetően osztrák kutatók problémafelvetése inspirálta (Klimek, Yegorov, Hanel, Thurner 2012). Tapasztalataink arra világítottak rá, hogy a térbeliség figyelmen kívül hagyása torzított becslésekhez vezet. A térbeli hatás mérésével igyekeztünk állításunkat alátámasztani, amelynek során a Getis-féle térbeli szürésre támaszkodtunk. Az eljárás a hazai szakirodalomban kevéssé gyakori eljárás, míg nemzetközi alkalmazására számos példát találunk a legkülönfélébb tudományterületekről. A teljesség igénye nélkül egyaránt utalhatunk a térbeli demográfiai (Benza 2013; Weeks, Getis, Hill, Gadalla, Rashed 2004), a térbeli kriminológiai (Bernasco, Elfers 2010; Getis 1995) vagy a közgazdasági-ökonometriai alkalmazásokra (Battisti, Di Vaio 2009; Mayor, López 2009).

Választáskutatási szempontból fontosnak tartjuk hangsúlyozni, hogy az adatok elemzése egyértelműen igazolta azokat a felvetéseket, amelyek a válasz- 
tói viselkedés térbeli jellegzetességeire utalnak. Véleményünk szerint a választói viselkedés elemzésekor mindenképpen kiemelt figyelmet kell fordítani erre a tényre, és bízunk benne, hogy az elméletekbe is egyre inkább beépül a térbeli nézőpont, amely segítségével képesek lehetünk megfelelő becsléseket létrehozni. Ugyanakkor a térbeli függőség, a választói magatartás hasonlóságának okaira e módszer sem ad megfelelő választ. E helyütt csupán néhány megközelítésre utalhatunk, amelyek kísérletet tesznek a részvétel és a térbeliség összekapcsolására. Az Egyesült Államokban már a hatvanas években kísérletek történtek a térbeli komponens szerepének megvilágítására a választási magatartásban (Huckfeldt 1979; Putnam 1966). Johnston és szerzőtársai (2001) arra hívták fel a figyelmet, hogy a társas kapcsolatok közül a vélemények befolyása jelentősebb, ha azok a közvetlen szomszédsági környezetből származnak. Cho és Rudolph (2008) tanulmányukban olyan közvetítő mechanizmusokra helyezték a hangsúlyt, amelyek az egymáshoz közeli lokalitásokban élők cselekvéseinek hasonlósága mögött húzódhatnak. A mikro-makro átmenet magyarázatát négy oksági kapcsolatra vezették vissza:

1. A politikai részvétel térbeli függőségeinek okai közül elsőként a szelekciós folyamatok szerepét emelték ki, amely a lakóhelyválasztás státus szerinti elrendeződésére utal. A szegregációs folyamatok miatt a homogén lakóhelyi környezetben élők gondolkodásmódja, ízlésvilága, választási hajlandósága és preferenciái is hasonlók. A kiválasztás szempontjából voltaképpen lényegtelen, hogy a szegregáció milyen mechanizmusokon keresztül megy végbe (etnikai vagy gazdasági kényszerek, diszkriminatív eljárások). A hangsúly az elkülönülésen és az elkülönültek politikai gyakorlatainak, participációs magatartásának a hasonlóságán van. Az önkiválasztási nézet szerint a kontextuális hatást olyan lakóhely-választási mechanizmusok hozzák létre, amelyek mögött egyéni tényezők állnak, ezek adnak térben csoportosuló mintázatot.

2. Második lehetőségként az elit mobilizációs szerepét emelték ki. Eszerint az elitek egyes célcsoportok választási részvételét célzottan igyekeznek növelni. A legegyszerúbben mindez földrajzi területek lehatárolásával, a helyi médiában elhelyezett üzenetekkel történhet.

3. A kontextuális hatások harmadik és valószínủleg legmeghatározóbb oka a társas interakciók elméletére vezethetö vissza, amely a társas környezet szerepét hangsúlyozza a lakóhelyi vagy a tágabb környezeti normák követésében. Makroszintű nézőpontból számos bizonyíték van arra, hogy a részvétel valószínűségét a lakóhely gazdasági, társadalmi, etnikai tényezői érdemben befolyásolják. Mikroszintű nézőpontból a hálózatok véleményformáló szerepét hangsúlyozzák az egyének participációs hajlandóságára.

4. Végül a hasonlóság irányába ható negyedik okot oksági észlelésnek nevezték. A társas interakciók explicit formáinál a hangsúly az önkéntes szervezetekben vagy véleményformáló hálózatokban való közvetlen részvételben van, azonban léteznek ezektől eltérő, nem kevésbé hatásos 
fórumok is, amelyek nem önkéntes alapon, nem zárt közösségek intim keretein belül gyakorolnak hatást. Az ilyen alacsony intenzitású szomszédsági kapcsolatok verbális és nem verbális csatornákon keresztül, közvetlen módon, akaratlagosan jelentkeznek a hétköznapi cselekvésekben, legtöbbször a lakókörnyezetben élők megfigyelése során.

Az általunk elérhető adatok nem teszik lehetővé a közvetítő mechanizmusok közötti sorrend megállapítását. Egy kellően széles térbeli lefedettségü exit poll-vizsgálat választ adhatna erre a kérdésre is, ilyen adatfelvétel azonban egyelőre nem érhető el hazánkban.

\section{Köszönetnyilvánítás}

Tóth Gergely publikációt megalapozó kutatása a TÁMOP 4.2.4.A/2-11-1-2012-0001 azonosító számú Nemzeti Kiválóság Program - Hazai hallgatói, illetve kutatói személyi támogatást biztosító rendszer kidolgozása és múködtetése országos program című kiemelt projekt keretében zajlott. A projekt az Európai Unió támogatásával, az Európai Szociális Alap társfinanszírozásával valósul meg.

\section{Jegyzetek}

1 Egy korábbi munkánkban hasonló eljárással Pécs szavazóköri adatait dolgoztuk fel. A forráskód itt érhető el: https://github.com/daroczig/PECS-2010/blob/master/valasztokorzetekpecs.R

2 A szomszédság meghatározásához az R statisztikai szoftver spdep csomagját használtuk (Bivand et al. 2013a; Bivand, Pebesma, Gómez-Rubio 2013b).

3 A szűrést Robert Ferstl MATLAB-parancssorával végeztük (Ferstl 2007a; 2007b).

\section{Irodalom}

Angelusz R., Tardos R. (2005): Választási részvétel és politikai aktivitás In: Angelusz R., Tardos R. (szerk.): Törések, hálók, hidak. Választói magatartás és politikai tagolódás Magyarországon. Demokrácia Kutatások Magyar Központja Alapítvány, Budapest, 323-384.

Bálint L., Bozsonyi K. (2011): Választói részvétel és véleménypolarizáció összefüggésének térökonometriai modellezése. In: Tardos R., Enyedi Zs., Szabó A. (szerk.): Részvétel, képviselet, politikai változás. Demokrácia Kutatások Magyar Központja Alapítvány, Budapest, 57-73.

Bálint L., Bozsonyi K.(2012): Választói részvétel és véleménypolarizáció térfilterezett modelljei. In: Kmetty Z., Koltai J. (szerk.): Változó képletek, változatos perspektívák. Tanulmánykötet Tardos Róbert 65. születésnapjára. Háttér Kiadó, Budapest, 251-274.

Battisti, M., Di Vaio, G. (2009): A spatially-filtered mixture of $\beta$-Convergence Regressions for European regions, 1980-2002. In: Baltagi, B. H., Arbia, G. (eds.): Spatial econometrics. Methods and applications, Physica-Verlag, Heidelberg, 105-122. 
Benza, M. (2013): Living arrangements and fertility: A case study of Southern Ghana. In.: Weeks, J.R., Hill, A. G., Stoler, J. (eds.): Spatial inequalities: Health, poverty, and place in Accra, Ghana. Springer, Dordrecht, 143-157.

Bernasco, W., Elfers, H. (2010): Statistical analysis of spatial crime data. In: Piquero, A. R., Weisburd, D. (eds.): Handbook of quantitative criminology. Springer, Dordrecht, 699-724.

Bivand, R. S. et al. (2013a): spdep: Spatial dependence: weighting schemes, statistics and models. R package version 0.5-56. http://CRAN.R-project.org/package=spdep

Bivand, R. S., Pebesma, E., Gómez-Rubio, V.(2013b): Applied spatial data analysis with R. Second edition. Springer Science+Business Media, New York

Bódi F., Bódi M. (2011): Hol vannak a választók? Politikatudományi Szemle, 1., 51-74.

Cho, W. K. T., Rudolph, T. J. (2008): Emanating political participation: untangling the spatial structure behind participation. British Journal of Political Sciences, 2., 273-289.

Ferstl, R. (2007a): Spatial filtering with EViews and MATLAB. Austrian Journal of Statistics, 1., 17-26.

Ferstl, R. (2007b): Werkzeuge zur Analyse räumlicher Daten - eine Softwareimplementation in Eviews and Matlab. Diplomarbeit

Getis, A. (1995): Spatial filtering in a regression framework: Examples using data on urban crime, regional inequality, and government expenditures. In: Anselin, L., Florax, R. (eds.): New directions in spatial econometrics. Springer, Heidelberg, 172-185.

Getis, A., Griffith, D. (2002): Comparative spatial filtering in regression analysis. Geographical Analysis, 2., 130-140.

Getis, A., Ord, J. K. (1992): The analysis of spatial association by use of distance statistics. Geographical Analysis, 3.,189-206.

Gujarati, D. (2003): Basic econometrics. Fourth edition. McGraw-Hill, New York, London

Hajdú Z. (2006): A 20. századi magyar parlamenti választások választási földrajzi kérdései. Múltunk, 1., 137-169.

Hubai L. (2011): Magyarország XX. századi választási atlasza 1920-2000. I-III. + CD-ROM. Napvilág Kiadó, Budapest

Huckfeldt, R. R. (1979): Political participation and the neighborhood social context. American Journal of Political Science, 3., 579-592.

Johnston, R. J., Pattie, C. J., Dorling, D. F. L., MacAllister, I., Tunstall, H., Rossiter, D. J. (2001): Social locations, spatial locations and voting at the 1997 British general election: evaluating the sources of Conservative support. Political Geography, 1., 85-111.

Klimek, P., Yegorov, Y., Hanel, R., Thurner, S. (2012): It's not the voting that's democracy, it's the counting: Statistical detection of systematic election irregularities. Statistics and Physics, 41., 169-173.

Kmetty Z., Tóth G. (2011): A politikai részvétel három szintje. In: Tardos R., Enyedi Zs., Szabó A. (szerk.): Részvétel, képviselet, politikai változás. Demokrácia Kutatások Magyar Központja Alapítvány, Budapest, 75-115.

Kovacs Z., Dingsdale, A. (1998): Whither East-European democracies? The geography of the 1994 Hungarian parlamentary election. Political Geography, 4., 437-458.

Lijphart, A. (1997): Unequal participation: Democracy's unresolved dilemma. American Political Science Review, 1., 1-13.

Martis, K. C., Kovacs, Z., Kovacs, D., Peter, S. (1992): The geography of the 1990 Hungarian parliamentary elections. Political Geography, 3., 283-305.

Mayor, M., López, A. J. (2009): Spatial shift-share analysis versus spatial filtering: an application to Spanish employment data. In: Baltagi, B. H., Arbia, G. (eds.): Spatial econometrics. Methods and applications. Physica, Heidelberg. 126-142.

Mészáros J., Szakadát I. (1998): Magyarország politikai atlasza. Osiris, Budapest

Mészáros, J., Solymosi N., Speiser F. (2007): Spatial distribution of political parties in Hungary 1990-2006. Political Geography, 7., 804-823.

Putnam, R. D. (1966): Political attitudes and the local community. American Political Science Review, 3., 640-654.

Ord, J. K., Getis, A. (2001): Testing for local spatial autocorrelation in the presence of global autocorrelation. Journal of Regional Science, 3., 411-432. 
Tardos R. (2011): Konszolidált szavazóközönség eróziós tendenciákkal. A 2010-es választások a részvételi aktivitás és szavazói motívumok fényében. In: Enyedi Zs., Szabó A., Tardos R. (szerk.): Új képlet. Választások Magyarországon, 2010. Demokrácia Kutatások Magyar Központja Alapítvány, Budapest, 273-374.

Weeks, J. R., Getis, A., Hill, A. G., Gadalla, M. S., Rashed, T. (2004): The fertility transition in Egypt: Intraurban patterns in Cairo. Annals of the Association of American Geographers, 1., 74-93.

http://www.vokscentrum.hu (Letöltés: 2014. február 28.) 